\title{
Vitality of Public Open Space (Case Study: Taman Nostalgia Kupang)
}

\author{
Hikmah \\ Construction Engineering Department, \\ Universitas Nusa Cendana, Jl. Adisucipto Kupang \\ Rosvitayati Umbu Nday \\ Architecture Department, \\ Universitas Nusa Cendana, Jl. Adisucipto Kupang \\ Ariency K. Manu \\ Civil Engineering Department, \\ Universitas Nusa Cendana, Jl. Adisucipto Kupang
}

Doi: 10.2478/mjss-2018-0081

\begin{abstract}
The purpose of the study is to determine the condition of Taman Nostalgia in terms of vitality (the quality of function, physic (environment), and meaning). The study implements descriptive approach, by which the study presents and describes the condition of Taman Nostalgia based on the phenomenon found in the field. The data are collected through documentation, observation, and interviews and are analyzed using descriptive approach and Project for Public Space. The results showed that the condition of Taman Nostalgia in terms of vitality has decreased due to several causes, such as the direct connection between relaxing area and garden area, the location and capacity of the plaza which is limited and not functional, direct connection between playground and plant area, the absence of space marker and the division of sub space in the parking area, the placement of jogging track separated and not connected to the centre of park activity, unattractive culinary area and its forming activities, limited space of sports centre, and unavailability of supporting facilities. Likewise, seen from the aspects of forming quality of the area, the park showed the absence of management concerning the aspect of needs (comfort, relaxation, passive/active engagement, and discovery), user rights (access and ease of achievement, freedom of action, claim, and change), and meaning (legibility, relevance between cultural norms and the user, individual connection, group connection, connection to larger society, biological connection, and connection to other world).
\end{abstract}

Keywords: vitality, public open space, Taman Nostalgia

\section{Introduction}

Development and dynamics of urban life, said Yunus (2008), have relevance to addressing the needs of joint spaces (public space). Life in public spaces includes public interest and private interests so that the fulfilment of a good public space should be pursued. Public open space is an open space outside the building, the place or space that has a particular meaning for the occupants or users (Ernawati, 2011) and can be used together by the public and provide an opportunity for a variety of activities that can strengthen the bonds of a community (Carr, 1995). The primary basis in creating a good (qualified) public space is working to meet the needs of its users regarding comfort and satisfaction of users that have a wide range of interests and backgrounds, such as social, economic and cultural. Hakim $(1987)^{[4]}$ stated that open public space is basically a space for community, either as individual or group, to hold particular activities. Public space is a place to interact, share, and perform activities together, including social, economical, and cultural interaction emphasizing on social activities. Furthermore, Carr (1995) emphasized the understanding of public 
space in the aspect of the fulfilment of all needs related to comfort and the satisfaction of users with diverse interests and backgrounds. In addition to meeting the needs, public space should be able to protect the rights of users in accordance with its functions and provide environmental (physical) facilities. In line with this notion, Hatmoko (cited in Mulyandari, 2010) classified public space based on the character that is formed into the shape of space (square, street, quarters, and pedestrian), the character of space cover (hard/soft), spatial orientation (inside, outside, and without orientation), and the use of space (active, semi active, and passive).

Kupang is a city that has the same trend as other growing cities in Indonesia. As a growing city, it absolutely has brought consequences for the urban problems which are difficult to overcome. The existence of public open space in the city of Kupang is deemed urgency in responding to and tackling the phenomena and dynamics. Taman Nostalgia is the sole open space located at the centre of the city. Based on its existence, it illustrates that people tend to be oriented in the park, but it is not the case. The tendency of people is lately more oriented to a number of open spaces on the coast. This shows the apprehension as well as enables the declining of vitality of Taman Nostalgia as the preliminary hypothesis in the study. Vitality is closely linked to the quality of space that provides an overview of the quality of a particular environment.

In connection with this view, the results of assessments in the study illustrated that a decline has occurred in the vitality of Taman Nostalgia in the aspects of quality, which are: function or activity, physical quality (environment), and visual quality (meaning). The decline in the quality of function indicates a change in the function of the park spaces that do not work properly. This triggers disorder and unclear linkages between activities or functions of space with physical forming elements. Functions that should be the embodiment of the provision of facilities showed a tendency of incompatible activities going on in the park. The physical quality problems associated with physical forming elements of garden space is the forming elements that do not have unequivocal characteristics causing ambiguity of functions, activities, and border between spaces. In addition, conditions of the physical elements that are damaged and poorly maintained trigger a decline in visitors who even merely orient toward particular spaces. The overview of changes in the function and physical condition reflects the change of meaning captured over the years.

\section{Research Method}

Based on the purpose, the study is classified as an applied research, while based on the data; the study is a survey research. The study was conducted in Kupang, precisely at Taman Nostalgia. Taman Nostalgia is a city park that was inaugurated in February 8, 2011, located in the centre of Kupang, Fatululi Village, Oebobo District. The site is on local government area of the city of Kupang with a high level of accessibility because it relates directly to the main road (JI. Frans Seda) which connects one region to another region.

The study population was the community/residents who live around the park, users/visitors of the park, and culinary seller in the park area. The sampling technique used for residents nearby the garden and culinary sellers is random sampling, while users/visitors of the park used incidental sampling technique. The sample size is set based on the argument of Widodo (2000) that if the population is homogeneous, the sampling is at least $5 \%$ of the total population.

Descriptive analysis was implemented to conduct the test, in which the results of research is presented and described to give meaning to the phenomena obtained in the field, with the steps as follows: (a) data observation and documentation that are qualitative in the form of drawings or descriptions of intangible facts served and described by the meaning of the condition of the park vitality; (b) conducting a study based on the theory of the vitality of public space refers to the Project for Public Space.

\section{Results and Discussion}

\subsection{Overview of Nostalgia Park Conditions}

Taman Nostalgia is the only public open space in the city of Kupang. It is strategically located in the 
downtown area of Kupang, precisely around local government area of the city of Kupang restricted directly with a primary arterial road (Jl. Eltari II, Fatululi) which connects parts of the area in Kupang. Taman Nostalgia has a square-shaped space character and have active spaces dominated by recreational activities and sports. It has several facilities including relaxing area, plaza, playground, sports centre, jogging tracks, culinary area, and parking area. Physical forming elements of Taman Nostalgia are explained as follows:

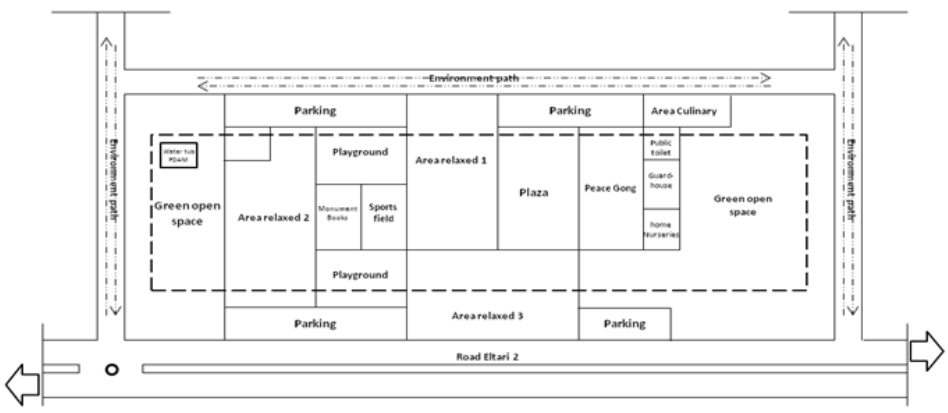

Figure 1. Sketch Space Nostalgia Park

\subsubsection{Relaxing Area}

Relaxing area is divided into three points adjusting to the physical forming element. The physical forming elements of relaxing area are garden and seating facilities. Relaxing area can still be used, but there are some concrete seat that are already broken and garden that is not maintained properly causing the plants dry out even some parts do not have a shade plant and trimmings

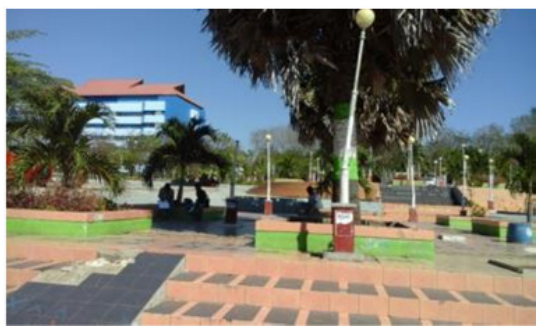

Figure 2. Relaxing Area

\subsubsection{Plaza}

The plaza is in the form of a shared lounge area which is relatively narrow that leads to limited space with different floor height pattern to provide a varied experience of space. The floor and paving material has largely been damaged. Since it is not supported by adequate illumination, evening activities are rarely found due to the dark space.

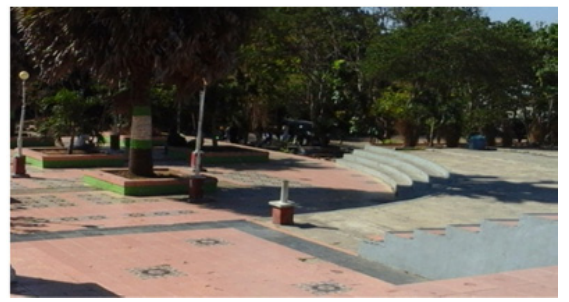

Figure 3. Palaza 


\subsubsection{Playground}

The park has several children's game facilities. Since the park is not maintained properly, children's game facilities are damaged and do not work. In addition, floor and paving materials connected to relaxing area which has been damaged and few shade plants make the park rarely used in the daytime.

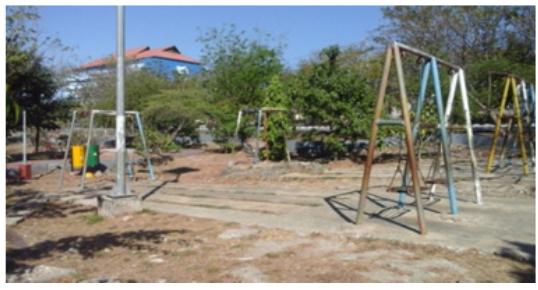

Figure 4. Playground

\subsubsection{Jogging Track}

Jogging track is a path that connects spaces of the park. Jogging track has a width of $1.5 \mathrm{~m}$ with paving material. The condition is relatively good. Only a few parts of the track have been damaged. The track actually does not support jogging activities for it is lack of rest area and shade area.

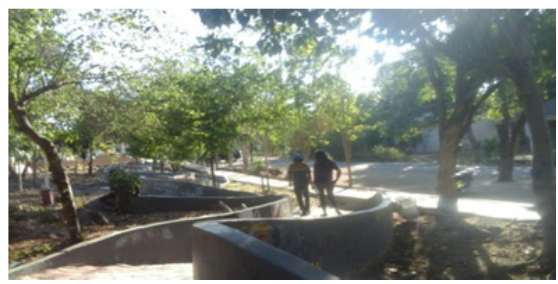

Figure 5. Area jogging track

\subsubsection{Culinary Area}

Culinary area is located around green open space. This area is much visited especially during afternoon and evening, while in the morning until afternoon it is relatively quiet. The structuring of culinary area follows the path associated with parking area to allow visitors to the site. However, at night the visitors tend to park the vehicle not in the parking area which disturbs the circulation of public roads. Culinary building is in the form of carts and tents which are not well arranged that give unattractive impression. In general, not permanent tents with varying shapes and sizes can lead to differences in the circulation space among culinary booths.

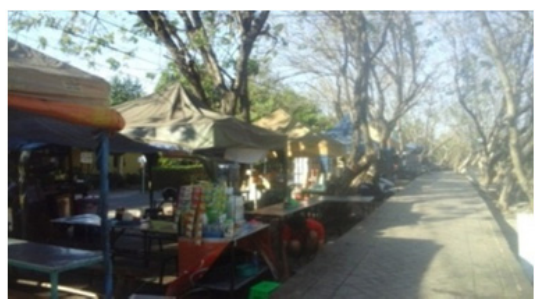

Figure 6. Area Culinary Vendors 


\subsubsection{Parking area}

The parking area is located in Jalan Eltari and streets around the park. The area which is relatively narrow and limited results in insufficient capacity, triggered by visitors who often park irregularly. The condition is relatively good, especially that around the Eltari. However, some of the paving material has been damaged that makes it even improper as a parking area.

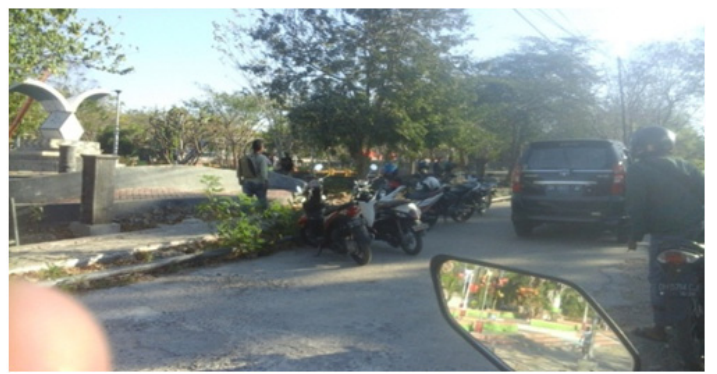

Figure 7. Parking Area

\subsection{Discussion}

The results showed a description that the vitality of Taman Nostalgia has decreased, that include the quality of function, physic (environment), and meaning in some garden spaces, such as relaxing area, plaza, playground, parking area, jogging track, culinary area, and sport centre. The quality deterioration is closely related to the visual experience when people (visitors) in a place so that they form a visual image of the place. It is in the form of connection between the order of activities or users (visitors) and the physical forming elements. The description of factors triggering the decrease in the vitality of the park is presented in table 1.

Tabel 1. The Analysis of Triggers for Problems in Taman Nostalgia

\begin{tabular}{|c|c|c|c|c|}
\hline \multirow[b]{2}{*}{ Space } & \multicolumn{2}{|l|}{ Indicator } & \multirow{2}{*}{\multicolumn{2}{|c|}{$\begin{array}{l}\text { - Connection (activities/users, Triggers } \\
\text { physic \& meaning) }\end{array}$}} \\
\hline & Structure of activities/users & $\begin{array}{l}\text { Physical } \\
\text { element }\end{array}$ & & \\
\hline $\begin{array}{l}\text { Relaxing } \\
\text { area }\end{array}$ & $\begin{array}{l}\text { Mostly joint activities like sitting } \\
\text { and chatting with group or } \\
\text { community in the plant area }\end{array}$ & $\begin{array}{l}\text { Seats directly connected } \\
\text { to the area of shade } \\
\text { plants and houseplants }\end{array}$ & $\begin{array}{l}\text { Connection between users and } \\
\text { function/activities of space } \\
\text { which are close like in relaxing } \\
\text { area triggers behaviour to } \\
\text { damage plants and throw the } \\
\text { waste in the area }\end{array}$ & $\begin{array}{l}\text { Direct connection } \\
\text { between relaxing } \\
\text { area and park }\end{array}$ \\
\hline Plaza & $\begin{array}{l}\text { Almost none of activities are } \\
\text { conducted in plaza due to limited } \\
\text { space and not strategic site to be } \\
\text { the centre of activities. This } \\
\text { allows visitors to maximize the } \\
\text { view from different point of view. }\end{array}$ & $\begin{array}{l}\text { Narrow space of plaza } \\
\text { makes it look like a } \\
\text { mere connector } \\
\text { between Reconciliation } \\
\text { Gong area and relaxing } \\
\text { area. It tends to be the } \\
\text { centre of activities in the } \\
\text { area. }\end{array}$ & $\begin{array}{l}\text { Limited capacity omits the } \\
\text { function of plaza as the centre } \\
\text { of orientation. The placement } \\
\text { which is not based on function, } \\
\text { shape, and space connection } \\
\text { causes the meaning of space } \\
\text { not expressed in the space } \\
\text { experience. }\end{array}$ & $\begin{array}{l}\text { Limited location } \\
\text { and capacity }\end{array}$ \\
\hline Playground & $\begin{array}{l}\text { Children activities allow them to } \\
\text { access the area of park. } \\
\text { However, the activities do not } \\
\text { support the comfort, especially } \\
\text { that in culinary area. }\end{array}$ & $\begin{array}{l}\text { The absence of border } \\
\text { between playground and } \\
\text { the area of plants. } \\
\text { Playing facilities is } \\
\text { limited and not handled } \\
\text { with care. }\end{array}$ & $\begin{array}{l}\text { The connection between space } \\
\text { border does not emphasize } \\
\text { limitation, penetration, and } \\
\text { addition of function so that the } \\
\text { activities created is not based } \\
\text { on area planning }\end{array}$ & $\begin{array}{l}\text { Space directly } \\
\text { connected to plant } \\
\text { area }\end{array}$ \\
\hline $\begin{array}{l}\text { Parking } \\
\text { Area }\end{array}$ & $\begin{array}{l}\text { Tendency of visitors to park } \\
\text { vehicles irregularly and not based } \\
\text { on restricted function of allotment }\end{array}$ & $\begin{array}{lcr}\text { Narrow space } & \text { and } \\
\text { limited capacity, the } \\
\text { absence of signs for } \\
\text { cars or motorcycle }\end{array}$ & $\begin{array}{l}\text { Area sign as the basis of sub- } \\
\text { area division for parking is not } \\
\text { clearly reflected. It causes } \\
\text { misplacement of activities. }\end{array}$ & $\begin{array}{l}\text { Area signs and } \\
\text { sub-area division }\end{array}$ \\
\hline
\end{tabular}




\begin{tabular}{|c|c|c|c|c|}
\hline \multirow[b]{2}{*}{ Space } & \multicolumn{2}{|l|}{ Indicator } & \multirow{2}{*}{\multicolumn{2}{|c|}{$\begin{array}{l}\text { Connection (activities/users, Triggers } \\
\text { physic \& meaning) }\end{array}$}} \\
\hline & Structure of activities/users & $\begin{array}{ll}\text { Physical forming } \\
\text { element }\end{array}$ & & \\
\hline $\begin{array}{l}\text { Jogging } \\
\text { track }\end{array}$ & $\begin{array}{l}\text { Activities in jogging track are } \\
\text { relatively absent and it is mostly } \\
\text { used in the evening. At night, the } \\
\text { function of jogging track is often } \\
\text { used for negative activities due to } \\
\text { the location which is separated } \\
\text { from main activities of the park. }\end{array}$ & $\begin{array}{l}\text { Jogging track does not } \\
\text { have rest area/shade } \\
\text { area and park area. The } \\
\text { connector between } \\
\text { spaces in the park to } \\
\text { create various space } \\
\text { experiences is not } \\
\text { provided. }\end{array}$ & $\begin{array}{l}\text { Connection between the centres } \\
\text { of activities is not planned } \\
\text { based on development and } \\
\text { indication that might appear. } \\
\text { Centres of activities are not } \\
\text { provided and emphasized } \\
\text { evenly in every space that } \\
\text { causes the change of function. }\end{array}$ & $\begin{array}{l}\text { The placement } \\
\text { which is } \\
\text { separated and not } \\
\text { connected to the } \\
\text { centre of activities } \\
\text { of the park }\end{array}$ \\
\hline $\begin{array}{l}\text { Culinary } \\
\text { Area }\end{array}$ & $\begin{array}{l}\text { The crowds tend to be in culinary } \\
\text { area in the evening. Visitors } \\
\text { spend most of the time in culinary } \\
\text { area rather than other areas. }\end{array}$ & $\begin{array}{l}\text { Facilities in culinary area } \\
\text { are very limited, such as } \\
\text { carts and tents, which } \\
\text { looks like the absence of } \\
\text { planning in building the } \\
\text { area. }\end{array}$ & $\begin{array}{l}\text { Living activities reflect a high } \\
\text { crowd. The formation of } \\
\text { function/activity is not a full } \\
\text { reciprocal relation of providing } \\
\text { facilities, for it adjusts to the } \\
\text { context. }\end{array}$ & $\begin{array}{l}\text { Area and the } \\
\text { forming activities } \\
\text { are not } \\
\text { interesting. }\end{array}$ \\
\hline $\begin{array}{l}\text { Sport } \\
\text { Centre }\end{array}$ & $\begin{array}{l}\text { The field is not functioned all the } \\
\text { time. The activities are mostly } \\
\text { carried out in the evening and are } \\
\text { limited to several kinds of sports. } \\
\text { Easiness to watch the sport } \\
\text { match is restricted by hampering } \\
\text { facilities. Limited capacity of area } \\
\text { triggers the decrease of visitors to } \\
\text { use the facility. }\end{array}$ & $\begin{array}{l}\text { The sole field is not } \\
\text { supported by rest area, } \\
\text { small tribune, and shade } \\
\text { area. Sports field } \\
\text { capacity does not meet } \\
\text { the number of users. }\end{array}$ & $\begin{array}{l}\text { Sustainability of activity is in line } \\
\text { with the provision of facilities. } \\
\text { Limited spaces supporting } \\
\text { sports activities lead sports } \\
\text { activities at certain times with } \\
\text { low intensity. }\end{array}$ & $\begin{array}{l}\text { Limited Space } \\
\text { and unavailability } \\
\text { of supporting } \\
\text { facilities }\end{array}$ \\
\hline
\end{tabular}

Source: Researchers' Analysis (2016)

Table 1 explained that there are triggering factors causing the decline in the vitality of the park, seen from three main indicators, which are the order of activities/users, physical forming element, and connectedness (activities/users, physic, and meaning). The results showed that in general the vitality of all parts of space in Taman Nostalgia has decreased. The triggering factors summed up are: (1) relaxing area (the arrangement of edges without considering reciprocal relation among users, activity, and physical elements cause the tendency of inappropriate behaviour); (2) plaza (connection of spaces that restrict the orientation centre did not confirm the level of space function, making it difficult in determining the orientation centre); (3) playground (connection of spaces that is not planned well lead to not optimal activity and space function); (4) parking area (determination of subspace is unknown that create activity incompatible with its functions); (5) jogging track (lack of affirmation of the function/activity that is formed results in a change of space function); (6) culinary area (relatively same activity over the time leads to low attractiveness of the space even though the facilities provided are sufficient); and (7) sport centre (limited space and unavailability of supporting facilities lead to the sustainability of the activity with low intensity).

In connection with the results, Garnham (2005) emphasized that the measure in determining the quality of the space is the order of the activities that are done and how it relates to the elements forming the physical order of the region. Furthermore, Haryanti (2008) argued that qualified space is not merely a space but a place for an integration between users and the space and is a space which has a distinctive character. Likewise, Darmawan (2003) emphasized that the qualified public space includes the meaning of the existence of the public spaces in the context of sustainability that meets the eligibility, such as functional quality, visual quality, and environment (physical and nonphysical). The quality of public spaces is associated with some aspects of equity and access. It is intended to fulfil human needs in a public space and ease of access in it (Lynch (1990). In relation to the creation of quality of public spaces, Carr (1995) emphasized that understanding on public space includes; (1) fulfilment of all the requirements regarding comfort and satisfaction of users who have different social, economic, and cultural background; (2) the role of public space which is required to always be responsive to development and change. In addition to meeting the needs, public space must also protect the rights users; and (3) the quality of public spaces which must have a meaning formed in history and culture. Furthermore, Carr (1995) provided an analysis of aspects of the establishment of the quality of public spaces such as presented in table 2 . 
Table 2. Analysis of the aspects of forming quality of public space

\begin{tabular}{|c|c|c|}
\hline Aspect & Factors & Analysis of connectedness of aspects and conditions of Taman Nostalgia \\
\hline Needs & Comfort & $\begin{array}{l}\text { Convenience is not optimal, especially psychologically against a hot climate (lack of shade } \\
\text { plants to reduce heat), supporting facilities (minimal number of facilities, damaged } \\
\text { facilities), and pedestrian crossing (similar surface using paving). }\end{array}$ \\
\hline & Relaxation & $\begin{array}{l}\text { Activities are deemed not fully provide relaxation to visitors (because of the noise factor, } \\
\text { assimilation activity at some functions that do not provide comfort and security) }\end{array}$ \\
\hline & passive involvement & $\begin{array}{l}\text { User involvement in social activities such as viewing and dialogue is not realized explicitly. } \\
\text { This is caused by the function of space which is not easy for users to communicate or } \\
\text { observe the conditions of the facility which are not well maintained }\end{array}$ \\
\hline & active involvement & $\begin{array}{l}\text { User involvement in exploring the park space is often hindered by incompatible functions of } \\
\text { activities. Events/performances tend to not periodically happen so that the active } \\
\text { involvement of users is very difficult to occur. }\end{array}$ \\
\hline & Invention & $\begin{array}{l}\text { Ease of reaching detailed landscaping facilities does not support because some facilities } \\
\text { are not maintained and even do not work. }\end{array}$ \\
\hline Rights & $\begin{array}{l}\text { Access and ease of } \\
\text { achievement }\end{array}$ & $\begin{array}{l}\text { Availability of access in open spaces of the park is not supported by the condition of the } \\
\text { facility. The facilities are even hindering visitors to achieve certain functions, such as } \\
\text { hindered by other activities, inadequate lighting, etc. }\end{array}$ \\
\hline & Freedom & Freedom to interact quite well to reach of all available facilities \\
\hline & Recognition & $\begin{array}{l}\text { Usage is quite responsive to the interests of society but do not adapt to the development of } \\
\text { current activity that demands the development of facilities }\end{array}$ \\
\hline Meaning & Legibility & $\begin{array}{l}\text { Legibility is not materialized, causing confusion and irregularities such as connecting line, } \\
\text { edge, the division of space, and area landmarks. }\end{array}$ \\
\hline & Linkages & $\begin{array}{l}\text { Connection between the user and cultural norms are not clearly defined. This resulted in } \\
\text { space design that did not express local culture norms. }\end{array}$ \\
\hline & Individual Relation & $\begin{array}{l}\text { Placement of space for specific classifications such as playground facilities exists, but the } \\
\text { facilities provided are relatively limited. }\end{array}$ \\
\hline & Group Relations & $\begin{array}{l}\text { There are spaces for groups such as sport centre, plaza for events/shows, but the activities } \\
\text { only take place at certain times }\end{array}$ \\
\hline & $\begin{array}{l}\text { Relation with the } \\
\text { public }\end{array}$ & $\begin{array}{l}\text { Relation with the public through the provision of special facilities, symbols, historical } \\
\text { symbols, and symbols of power do not seem. }\end{array}$ \\
\hline & $\begin{array}{l}\text { Biological and } \\
\text { psychological } \\
\text { relation }\end{array}$ & $\begin{array}{l}\text { Very strategic location of the park facilitates the orientation of society in the region. } \\
\text { However, the relation of natural elements does not seem like using natural materials. } \\
\text { Comfort and security are not provided well especially in the children's activities }\end{array}$ \\
\hline & $\begin{array}{l}\text { Relations with other } \\
\text { factors (climate) }\end{array}$ & $\begin{array}{l}\text { A very hot climate condition results in difficulties in the treatment of plant. Moreover, the } \\
\text { difficulties of water supply has exacerbated landscaping conditions such as drying crop, } \\
\text { etc. }\end{array}$ \\
\hline
\end{tabular}

Source: Carr (1955).

When Carr's aspects of quality of public space in table 2 are juxtaposed with the conditions of space in Taman Nostalgia, it indicates the absence of management concerning the aspect of needs, user rights, and meaning. To solve this problem, Carr (1995) stated strategy is needed for the establishment of quality of public space with respect to the aspect of: (1) need, which includes the management and improvement by considering: (a) comfort psychologically, biologically, and socially to climate, seating, supporting facilities, pedestrian crossing/ground surface, lighting, and plan space; (b) relaxation which is obtained in the move as public space that feels like relaxing on the local environment and comfort and safety of the park; (c) passive engagement, which is user's involvement in public space in terms of observing, viewing, and dialogue with the environment; (d) active engagement, that is user's involvement in public space in terms of moving through the park, communicating, events, children's playground, and adults' space; and (e) discovery for the move that may be a pedestrian crossing and details of landscape elements; (2) rights, that is the recognition of freedom of activity by considering several factors, such as: (a) access and ease of achievement by avoiding physical limits, avoiding visual obstructions, and providing symbol of access to public spaces for all communities; (b) freedom of action to all of part of the public space, which can be realized in the form of multi-use space for some activities, activity zones, protection against certain space; (c) claim for the use of space that is the separation of open space for the benefit of the public to deliver demand and program to control the use of space; and (d) change that is generated in near-term and longer term; (3) meaning, an aspect that is studied from of physical and non-physical aspect and social linkage and political history and culture with the following 
criteria: (a) legibility, that is clarity and regularity concerning about social node which connects line, clear but flexible area boundaries, division of area, landmark areas; (b) relevance between cultural norms and the user, formal quality of public space with other public spaces, design and management, naming the sub space depending on the context; (c) individual connection in the form of splitting poles in order to attract visitors, children's playground, and putting an important place for individuals; (d) group connection in the form of chamber groups (social level, ethnicity, etc.), space for sports groups, space to support arts activities; (e) connection to larger society which is usually in the form of a special place, a symbol of the continuity of history, economics and a symbol of power and others; ( $f$ ) biological and psychological connections in relation to the elements of nature, the main hall as the orientation of the surrounding space, a special space comfortable and safe for children; and $(\mathrm{g})$ connection to other world which is the relationship of macro and micro cosmic and climate.

\section{Conclusion}

Conditions of Taman Nostalgia in terms of vitality (the quality of function, physic (environment) and meaning) has decreased evoked by factors, such as direct connection between relaxing area and garden area, the location and capacity of the plaza which is limited and not functional, direct connection between playground and plant area, the absence of space marker and the division of sub space in the parking area, the placement of jogging track separated and not connected to the centre of park activity, unattractive culinary area and its forming activities, limited space of sports centre, and unavailability of supporting facilities. Likewise, seen from the aspects of forming quality of the area, the park showed the absence of management concerning the aspect of needs (comfort, relaxation, passive/active engagement, and discovery), user rights (access and ease of achievement, freedom of action, claim, and change), and meaning (legibility, relevance between cultural norms and the user, individual connection, group connection, connection to larger society, biological connection, and connection to other world).

\section{References}

Alfani, T. (2008). Pengaruh Waktu Terhadap Identitas dan Image Kawasan. Jakarta: Universitas Indonesia.

Stephen, C. (1995). Publik Space. Cambridge: University Press.

Danisworo, M. (1992). Arsitektur, Kota dan Lingkungan Hidup. Yagyakarta: ITB.

Darmawan, E. (2003). Teori dan Kajian Ruang Publik Kota. Semarang: Badan Penerbit Universitas Diponegoro.

Ernawati, J. (2011). Faktor-faktor Pembentuk Identitas Suatu Tempat. Journal of Local Wisdom. Volume: III, Number: 2, page: 01 - 09, April 2001.

Garnham, H.L. (1985). Maintaining the Spirit of Place: Process for Preservation of Town Character. Meza Arizona: PDP, Publisher Corporation.

Garnham, H.L. (2005). Culture, Place and Identity. Ireland: Univ College Dublin Pr.

Hakim, R. (2012). Komponen Perancangan Arsitektur Lansekap: prinsip-unsur dan aplikasi desain. Jakarta: PT. Bumi Aksara.

Haryanti, D.T. (2008). Kajian Pola Pemanfaatan Ruang Terbuka Publik Kawasan Bundaran Simpang Lima Semarang. Thesis. Region and City Development Engineering Department at Graduate Program of Universitas Diponegoro.

Heryanto, B. (2011). Roh dan Citra Kota. Surabaya: Brilian Internasional.

Lynch, K. (1990). The Image of the City. Cambridge: MIT Press, MA.

Mulyandari, H. (2011). Pengantar Arsitektur Kota: Yogyakarta: CV. Andi Offset.

Widodo, Erna and Mukhtar. (2000). Konstruksi ke Arah Penelitian Deskriptif. Yogyakarta: Avyrous.

Yunus, H.S. (2008). Dinamika Wilayah Peri-Urban Determinan Masa Depan Kota. Yogyakarta: Pustaka Pelajar. 